\title{
Pollination biology of Paliavana tenuiflora (Gesneriaceae: Sinningeae) in Northeastern Brazil
}

\author{
Patrícia Alves Ferreira ${ }^{1,2}$ and Blandina Felipe Viana ${ }^{1}$
}

Recebido em 22/10/2009. Aceito em 26/08/2010

\begin{abstract}
RESUMO - (Biologia da polinização de Paliavana tenuiflora (Gesneriaceae: Sinningeae) no nordeste do Brasil). No presente estudo a biologia floral, o sistema reprodutivo, os visitantes e os polinizadores de Paliavana tenuiflora foram analisados em campos rupestres na Chapada Diamantina, Mucugê, Bahia, Brasil. Paliavana tenuiflora é um arbusto com flores campanulares azul-violeta, com antese às 11:00 h, e duração das flores por

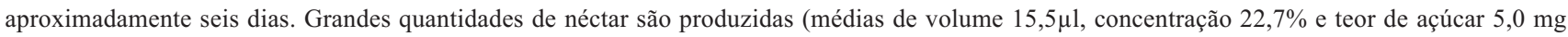
$\left.\mu \mathrm{L}^{-1}\right)$. A produção de néctar não está relacionada com o período do dia, mas a concentração variou com o volume. A espécie é autocompatível, mas a formação de frutos depende de polinizadores. Apesar do néctar estar disponível de dia e de noite, P. tenuiflora se encaixa na síndrome de polinização por abelhas e, de fato, é polinizada por Bombus brevivillus. Entretanto, o beija-flor Phaethornis pretrei pode ser considerado polinizador ocasional, devido a seu comportamento e a baixa freqüência de visitas. Os resultados sugerem um sistema de polinização misto, porém a importância de $P$. pretrei como polinizador precisa ser mais bem avaliada.
\end{abstract}

Palavras-chave: Campos rupestres, polinização, sistema reprodutivo, Bombus brevivillus, Phaethornis pretrei, Bahia

\begin{abstract}
Pollination biology of Paliavana tenuiflora (Gesneriaceae: Sinningeae) in Northeastern Brazil). In this study the floral biology, breeding system, visitors and pollinators of Paliavana tenuiflora were analyzed in campos rupestres in the Chapada Diamantina, Mucugê, Bahia, Brazil. Paliavana tenuiflora is a shrub with blue-violet, bell-shaped flowers, with anthesis at 11:00 h; the flowers last about six days. Large amounts of nectar are produced (volume average $15.5 \mu \mathrm{L}$, concentration $22.7 \%$ and sugar content $5.0 \mathrm{mg} \mathrm{mL}^{-1}$ ). The amount of nectar is not related to the time of day, but concentration varied with volume. The species is self-compatible, but fruit set depends on pollinators. Although nectar is available by day and night, flowers of $P$. tenuiflora fit the bee pollination syndrome, and are actually pollinated by Bombus brevivillus. However, the hummingbird Phaethornis pretrei can be considered an occasional pollinator, due to its behavior and low frequency of visits. Our results suggest a mixed pollination system, although the importance of P.pretrei as a pollinator remains to be better evaluated.
\end{abstract}

Key words: campos rupestres, pollination, breeding system, Bombus brevivillus, Phaethornis pretrei, Bahia

\section{Introduction}

Floral differences among species have been viewed as adjustments to different pollinators (Proctor et al. 1996; Barrett 1998; Fenster et al. 2004) and floral traits related to the form and behaviour of pollinators are described as pollination syndromes. Pollination syndromes are a group of flower traits that have evolved in response to selective pressure forced by different pollinators (Faegri \& van der Pijl 1979). Due to the evolutionary origin of these interactions and the role of pollinators in the selection of floral traits, pollination syndromes are good indicators of the current relationship between plants and pollinators (Herrera 1996; Fenster et al. 2004; Machado \& Lopes 2004). However, relationships between plants and pollinators tend to be more generalized and asynchronous, and more than one group of visitors may pollinate plants (Herrera 1996; Waser et al. 1996; Johnson \& Steiner 2000; Ashworth et al. 2004).

The genus Paliavana Vandelli (Gesneriaceae, Sinningeae) has species with characteristics mainly associated with the floral syndromes melittophily, ornithophily and chiropterophily (Wiehler 1983; Smith et al. 1997; Perret et al. 2001, 2003, 2006, 2007; Zimmer et al. 2002), and studies on Paliavana sister species may provide insights for the role of pollinators in the evolution of the pollination systems of these species (SanMartinGajardo \& Sazima 2005). Species of this genus have flowers that are diversified in form, color and nectar sugar composition, features that may be associated with differe nt groups of pollinators (Wiehler 1983; Perret et al. 2001; SanMartin-Gajardo \& Sazima 2005). The floral features of some species from southeastern Brazil suggest that they may be intermediate between different syndromes and have characteristics associated with distinct visitor groups. An example is Paliavana sericiflora Benth., which has flowers with intermediate characteristics between bird- and bat-syndromes, however, this species is visited and pollinated only by hummingbirds (SanMartin-Gajardo \& Sazima 2005).

In Paliavana tenuiflora Mansf., the floral traits (such as corolla color and shape, flower longevity, production of large quantities of concentrated nectar, and hercogamy and protandry) suggest the attraction of different visitors, such as bees, hummingbirds and bats, and that many (or all) of them may be important for reproductive success (Perret et

\footnotetext{
Universidade Federal da Bahia, Salvador, BA, Brazil
}

Author for correspondence: patybio13@yahoo.com.br 
al. 2001; SanMartin-Gajardo and Sazima 2005). However, Perret et al. (2007) classified this species as melittophilous due to corolla color and shape. Paliavana tenuiflora presents an interesting model to evaluate the role of pollination syndromes in determining the structure of plant-pollinator systems and the role of floral visitors as effective pollinators. Therefore, our goal is to provide the first record of the floral biology of $P$. tenuiflora and the role of floral visitors in its reproductive success.

\section{Methods}

Paliavana tenuiflora is a shrub with hermaphrodite flowers having a bell-shaped, violet-purple corolla, and high production of pollen and nectar (SanMartin-Gajardo \& Sazima 2005). This species occurs mainly on rocky outcrops in Pernambuco, Bahia, and Minas Gerais (Araujo et al. 2005).

The present study was undertaken in the Mucugê Municipal Park, in Chapada Diamantina, Bahia, Brazil (1259' S; 41⒉ 'W; 975 m a.s.1.), between March and May of 2007 and 2008, that corresponds to the flowering season of $P$. tenuiflora at that location. The area is characterized by open, low vegetation on sandstone rocky outcrops at altitudes of approximately $1000 \mathrm{~m}$ (Funch et al. 2002). Monthly rainfall during those periods was 93.3 $\pm 75.06 \mathrm{~mm}$ in 2007 and $103.8 \pm 47.68 \mathrm{~mm}$ in 2008 , while maximum and minimum temperatures varied between $25.9 \pm 0.68^{\circ} \mathrm{C}$ and $17.2 \pm 0.63^{\circ} \mathrm{C}$ in 2007 and $26.5 \pm 2.37^{\circ} \mathrm{C}$ and $17.7 \pm 1.86^{\circ} \mathrm{C}$ in 2008 ("Projeto SempreViva", unpublished data).

Thirty flowers on 15 different plants were observed in situ to determine phases of anthesis, floral morphology and color and scent emission (after Varassin et al. 2001; Dafni et al. 2005). Effective corolla length was measured on fresh flowers sampled from different plants $(\mathrm{n}=30$ flowers $)$ (Dafni et al. 2005). The presence of nectar guides was determined by observing ultraviolet light (UV) reflectance from the corolla using gray scale photography methods and UV filters ( $\mathrm{n}=30$ flowers) (Kevan et al. 1973). The sexual system was described in terms of the position and functioning of the reproductive structures (Dafni et al. 2005). Stigma receptivity was tested using the hydrogen peroxide $\left(\mathrm{H}_{2} \mathrm{O}_{2}\right)$ catalyse activity method during the first 24 hours after anthesis in one to three flowers of different plants (n $=30$ flowers). Pollen viability was estimated by cytoplasm staining using neutral Red dye (1\%) from 30 flowers (Kearns \& Inouye 1993).

Nectar production was measured in 32 flowers bagged in bud, from flower opening until 48 hours of anthesis (male phase) and from 48 hours of anthesis until senescence (female phase). Nectar volume was measured using a graduated microliter tube $(10 \mu 1)$. Sugar concentrations (sucrose percentage) were measured using a pocket refractometer (Sugar/Brix w/ ATC 300010) (Kearns \& Inouye 1993), and the total amount of sugar was calculated and expressed in milligrams (Corbet 2003; Dafni et al. 2005). In another group of nine bagged flowers of three different plants, all nectar was removed carefully from the flowers at regular two-hour intervals from 07:00 h until 16:00 $\mathrm{h}$ on the first day after anthesis, to verify the replacement capacity of nectar. Mean nectar volumes and sugar concentrations were measured and total sugar produced per time interval was calculated for the same group of nine flowers (Kearns \& Inouye 1993; Hernández-Conrique \& Ornelas 2007)

Manipulative experiments were performed to analyze the reproductive system. Tests of spontaneous self-pollination (SS) and manual selfpollination (SP) - transfer of pollen to the receptive stigma of the same flower - were conducted in 20 isolated flowers. Tests of cross pollination (CP) - manual transfer of pollen to the receptive stigmas of different flowers on plants separated by at least $500 \mathrm{~m}$ - were conducted in 24 isolated flowers. Control (natural pollination) was conducted in 22 unbagged flowers exposed to pollinators (procedures after Dafni et al. 2005). The results were evaluated based on the mean number of seeds per fruit in each treatment (Rivera-Marchand \& Ackerman 2006).

A total of $180 \mathrm{~h}$ of observation during seven days and nights was used to monitor floral visitors on 15 flowers from nine different plants at the same phenological phase and that had similar morphological conditions and age. We recorded visitation period, frequency and duration of visits, behaviour and number of visitors and numbers of flowers visited, as well as interaction between visitors. After the observation period we started sampling. Floral visitors were sampled during $113 \mathrm{~h}$ of collecting, when they were captured. Bees were collected with entomological nets (Sakagami et al. 1967) on 60 different plants and were identified (Kearns \& Inouye 1993). Specimens were deposited at MZUFBA (11.709 to 11.886).

We investigated the influence of sequential floral visits on fruit and seed set. Experiments were carried out on 336 flowers of 24 plants, 14 flowers in each experiment, chosen at random. We observed the flowers until they were visited once, twice, or three times by large bees (Kearns \& Inouye 1993), after which the flowers were bagged until fruit formation. We also did manipulative exclusion experiments to determine the relative efficiency of nocturnal and diurnal pollinators. Fourteen bagged flowers were tested in each treatment. One group of previously bagged flowers was kept exposed from $05: 30 \mathrm{~h}$ to $17: 30 \mathrm{~h}$; another group was kept exposed from 17:30 $\mathrm{h}$ to 05:30 h; while a third group of flowers was continually exposed. Flowers of diurnal or nocturnal treatments and of the control were left unbagged for three consecutive days (Giménez-Benavides et al. 2007). The mean number of seeds per fruit set after each treatment was used to ascertain the efficiency of nocturnal and diurnal visitors.

Multiple linear regression analyses were conducted to assess variations in nectar production (volume, concentration, and sugar content) in relation to the time of day. We used 31degrees of freedom. Other linear regression analyses were conducted to test sugar concentrations in relation to the volume of nectar produced (Quinn \& Keough 2002). Kruskal-Wallis Test was used to analyze the effects of the different pollination regimes on fruit and seed set. This test was standardized based on seed set in six fruits from each treatment (SS, SP, CP, and control) and we used 5 degrees of freedom. Kruskal-Wallis was used to analyze the difference among SP, CP, and Control (Shaw \& Mitchell-Olds 1993). Standardized Nonparametric ANOVA was also applied to determine pollinator efficiency in one, two or three visits and one way ANOVA was applied to determine the efficiency of nocturnal versus diurnal pollinators in terms of fruit and seed set, with 7 and 5 degrees of freedom, respectively in both tests (Underwood 1997). All the data were tested for linearity, homoscedasticity and normality, and we did not need to use data transformations. We used the reliability of $95 \%$ (Quinn \& Keough 2002).

\section{Results}

Flowers had an average corolla length of $71.31 \pm 4.05$ $\mathrm{mm}(60-80 \mathrm{~mm} ; \mathrm{n}=32$ flowers). Flowering occurred once a year and lasted from March to May. No osmophores, odor presence or UV reflectance were registered in the flowers. Flower opening began around 11:00 $\mathrm{h}$, and this phase lasted 18-20 hours. After this period the flowers remained open until senescence. Flowers lasted about six days. We observed a marked floral dichogamy, with hercogamy combined with protandry. The male phase is characterized by the release of viable pollen just after anthesis and the pollen is available for $48 \mathrm{~h}$ after flower opening ( $\mathrm{n}=30$ flowers). The stigma was receptive in early anthesis but on the first and second days, the style remained behind the anthers and was inaccessible to visitors. On the third day the receptive stigma grew beyond the anthers and became accessible to visitors (female phase). From this period on, the stigma is completely receptive and remains so until senescence of the flower. The average length of the style is $23.74 \pm 3.05 \mathrm{~mm}$, minimum $18 \mathrm{~mm}$ in pre-anthesis, and maximum $31 \mathrm{~mm}$, three days after flower opening ( $\mathrm{n}=27$ flowers).

Large quantities of nectar are produced by five glands surrounding the ovary and accumulate at the base of the flower tube $71.19 \pm 16.34 \mu \mathrm{l}$. A small amount of nectar is 
produced immediately after anthesis $(0.01 \pm 16.33 \mu \mathrm{l})$ but production increases gradually. When removed, nectar was replenished with equivalent volume, concentration, and sugar content. The average total volume of nectar produced was $15.45 \pm 16.34 \mu \mathrm{l}$, with an average sugar concentration of $22.69 \pm 10.15 \%$; and sugar content of $4.97 \pm 5.96 \mathrm{mg}_{\mu \mathrm{L}}^{-1}$. Variation in nectar production was not related to the time of day $\left(p=0.20 ; r^{2}=0.017 ; F=1.642\right)$. However, sugar concentrations varied according to the volume of nectar produced $\left(\mathrm{p}=0.0005 ; \mathrm{r}^{2}=0.33 ; \mathrm{F}=15.100\right)$.

Paliavana tenuiflora is self-compatible, however, fruit and seed set are dependent on active pollination. Significant differences were observed between SS, which did not set fruit, and other treatments $(\mathrm{p}=0.0013 ; \mathrm{KW}=15.726)$, but there was no difference between seed set in the three other treatments (SP, CP and Control, $\mathrm{p}=0.1090, \mathrm{KW}=4.433$ ). Although there was no significant difference between fruit and seed set after these treatments, more seeds were produced in CP and Control than in SP treatments (Tab.1).

Flowers were visited by bees, ants and wasps (Hymenoptera), beetles (Coleoptera), hummingbirds (Trochilidae) and spiders (Araneae) (Tab. 2). A total of 174 bees representing 15 species and ten genera of Apidae were collected. Large bees, including Bombus brevivillus Franklin, 1913, were the most abundant visitors to these flowers, accounting for approximately $75 \%$ of the total number of insect visitors. Small bees, such as Trigona spinipes (Fabricius, 1793) and Frieseomelitta francoi (Moure, 1946) (Meliponinae), were less frequent. Large bees were observed collecting nectar in the morning between 06:00 and 11:00 $\mathrm{h}$, although visits could continue until 17:30 $\mathrm{h}$. These bees landed on the flowers and collected the nectar accumulated at the bottom of the floral tube; movements and body size of the bee placed its back in contact with plant reproductive structures. The large bees visited one flower on each plant before moving to other plants.

Two species of hummingbirds were observed visiting the flowers of P. tenuiflora, Phaethornis pretrei (Lesson \& Delattre, 1839) (Phaethornithinae) and Chlorostilbon aureoventris (d'Orbigny \& Lafresnaye, 1838) (Trochilinae). Phaethornis pretrei visited all open flowers on each plant, introducing its beak into the flower tube to search for nectar. Sometimes this hummingbird would adopt an inverted position in relation to the flower, with its beak touching the bottom of the floral tube. This bird had a low frequency of visits, visiting the flowers mainly in the late afternoon and in rare episodes. Chlorostilbon aureoventris visited the flowers in a larcenous manner, puncturing the base of the corolla with its beak to retrieve nectar. The visits also occur in the late afternoon and in rare episodes.

Trigona spinipes often appeared in groups of two to five individuals and they were observed cutting floral parts (including the anthers). Visits were quick, lasting from three to ten seconds, and occurred throughout the day (although most frequently in the morning). Frieseomelitta franco $i$ visited these flowers to collect nectar at the corolla opening; visits lasted from three seconds to several minutes and occurred throughout the day. Less often, these bees were observed visiting flowers to collect pollen, at which time they entered the floral tube reaching the anthers. During these incursions the bees did not come in contact with the style.

Beetles visited the flowers to obtain floral parts and pollen. Ants and wasps were observed searching for nectar; even after corolla senescence, they visit the flowers throughout the day at irregular intervals. These visitors could be considered floral robbers, as they visit the flowers and take pollen and nectar, but do not touch the reproductive parts of the flowers during their visits. Spiders belonging to the genus Misumenops were observed outside the corolla and at its mouth in prey catching positions, and they were observed attacking floral visitors (mainly small bees). They were not observed preying on large bees. No floral visitors were observed at night during the entire monitoring period.

No fruit-set was observed in the 14 flowers that received only a single visit, while flowers visited two or three times produced fruits and seeds. An average of $2455 \pm 1138.44$ seeds were found in fruits resulting from two visits, and $2616.67 \pm 191.89$ seeds in fruits resulting from three visits. Fruits set under control conditions produced an average of $3330.67 \pm 597.44$ seeds. No significant differences were found between the average number of seeds produced by these three treatments $(\mathrm{p}=0.1786 ; \mathrm{KW}=3.806)$.

No fruit was set in the 14 flowers exposed only at night; fruit set was $43 \%$ for the 14 flowers exposed during the day and $100 \%$ in the 14 flowers of the control. Significant differences between these treatments were found $(p=0.0001 ; F=17.91)$.

\section{Discussion}

Our results show that in the campos rupestres study area, the large bee Bombus brevivillus is an efficient pollination

Table 1. Reproductive system of Paliavana tenuiflora in Mucugê, Bahia, Brazil. Data are the fruit and seed set after hand-pollination treatments.

\begin{tabular}{cccc}
\hline & Control & Spontaneous Self-Pollination (SS) & Manual Self-Pollination (SP) \\
\hline $\mathrm{N}^{\circ}$ individuals & 22 & 20 & 20 \\
Fruits/flowers & $22 / 22$ & $0 / 20$ & $12 / 20$ \\
Success (\%) & 100 & 0 & 60 \\
Average $\mathrm{n}^{\circ}$ seeds/fruit $\pm \mathrm{SD}$ & $3863,67 \pm 1045,1$ & - & 25 \\
\hline
\end{tabular}


Table 2. Flower visitors and pollinator agents observed and collected in Paliavana tenuiflora in Mucugê, Bahia, Brazil. Visitor categories: $\mathrm{O}=$ occasional pollinator; $\mathrm{L}=$ legitimate pollinator; $\mathrm{R}=$ pollen/nectar robber. Floral resources used by the visitors: $\mathrm{P}=$ pollen; $\mathrm{N}=$ nectar; $\mathrm{F}=$ floral tissue.

\begin{tabular}{|c|c|c|}
\hline Floral visitors & Category & Resource used \\
\hline \multicolumn{3}{|l|}{ INSECTA } \\
\hline \multicolumn{3}{|l|}{ HYMENOPTERA } \\
\hline \multicolumn{3}{|l|}{ Apidae } \\
\hline & $\mathrm{L}$ & $\mathrm{N}$ \\
\hline Bombus brevivillus Franklin, 1913 & $\mathrm{~L}$ & $\mathrm{~N}$ \\
\hline \multirow{2}{*}{ Epicharis sp. } & $\mathrm{L}$ & $\mathrm{N}$ \\
\hline & $\mathrm{L}$ & $\mathrm{N}$ \\
\hline Eulaema nigrita Lepeletier, 1841 & $\mathrm{~L}$ & $\mathrm{~N}$ \\
\hline Euplusia sp. & $\mathrm{R}$ & $\mathrm{N}, \mathrm{P}$ \\
\hline Centris fuscata Lepeletier, 1841 & $\mathrm{~L}$ & $\mathrm{~N}$ \\
\hline Frieseomelitta francoi (Moure, 1946) & $\mathrm{L}$ & $\mathrm{N}$ \\
\hline \multirow{2}{*}{ Epicharis flava (Friese, 1900) } & $\mathrm{R}$ & $\mathrm{F}, \mathrm{P}$ \\
\hline & $\mathrm{L}$ & $\mathrm{N}$ \\
\hline Eufriesea danielis Schrottky, 1907 & $\mathrm{~L}$ & $\mathrm{~N}$ \\
\hline Trigona spinipes (Fabricius, 1793) & $\mathrm{L}$ & $\mathrm{N}$ \\
\hline Eufriesea nigroirta Friese, 1899 & $\mathrm{~L}$ & $\mathrm{~N}$ \\
\hline Centris aenea Lepeletier 1841 & $\mathrm{~L}$ & $\mathrm{~N}$ \\
\hline \multicolumn{3}{|l|}{ Centris obsoleta Lepeletier 1841} \\
\hline \multicolumn{3}{|l|}{ Eulaema cingulata (Fabricius, 1804) } \\
\hline Thygater analis (Lepeletier, 1841) & $\mathrm{L}$ & $\mathrm{N}$ \\
\hline \multicolumn{3}{|l|}{ Xylocopa (Neoxylocopa) cearensis Ducke, 1910} \\
\hline Wasps & $\mathrm{R}$ & $\mathrm{N}$ \\
\hline Ants & $\mathrm{R}$ & $\mathrm{N}$ \\
\hline \multicolumn{3}{|l|}{ COLEOPTERA } \\
\hline Beetles & $\mathrm{R}$ & F, P \\
\hline \multicolumn{3}{|l|}{ ARANEA } \\
\hline \multicolumn{3}{|l|}{ Thomisidae } \\
\hline Misumenops sp. Cambridge, 1900 & - & - \\
\hline \multicolumn{3}{|l|}{ HUMMINGBIRDS } \\
\hline \multicolumn{3}{|l|}{ Phaethornithinae } \\
\hline Phaethornis pretrei (Lesson \& Delattre 1839) & $\mathrm{O}$ & $\mathrm{N}$ \\
\hline \multicolumn{3}{|l|}{ Trochilinae } \\
\hline Chlorostilbon aureoventris (D’Orbigny \& Lafresnaye 1838) & $\mathrm{R}$ & $\mathrm{N}$ \\
\hline
\end{tabular}

vector for P. tenuiflora, and its floral traits could be included in the melittophilous pollination syndrome. Despite these traits, the hummingbird Phaethornis pretrei is also attracted to the flowers and can act as pollinator due to its visiting behaviour. In the tribe Sinningieae, $93 \%$ of species exhibit the syndrome of pollination by bees or by hummingbirds, and the latter seems to be the ancestral condition for this group. Moreover, most changes in Sinningieae are between these two syndromes (Perret et al. 2003). Paliavana tenuiflora shows a pollination system that can be favored by the presence of bees. In this sense, this species has floral traits, such as size, color and shape of the flowers, and nectar sugar concentration, structurally related to pollination by bees, and is actually pollinated by bees, mainly by $B$. brevivillus. Although hummingbirds pollinate the flowers of this species, visits are rare, and its efficiency as a pollinator is unknown. 
Nectar characteristics of $P$. tenuiflora, such as high volume and sugar concentration, are related to bee pollination, as these animals are known to be attracted to flowers with sugar concentration averaging about 24\% (Corbet \& Willmer 1981; Baker et al. 1998; Perret et al. 2001; Chalcoff et al. 2006). The nectar availability of $P$. tenuiflora may induce bees to make multiple visits in order to fulfil their caloric needs. This situation may favor higher pollen dispersal, but it also may favor short-distance movements that would promote autogamy (Machado et al. 1998; Buzato et al. 2000; Wesselingh et al. 2000).

Paliavana tenuiflora flowers need more than one visit by bees to form fruits and seeds. Other features such as nectar accumulation at the base of the corolla, and replacement of nectar in the flowers after removal may attract large bees both to make more visits and to move their heads to the bottom of the flower. This behaviour results in the appropriate bee position to touch floral reproductive structures with the dorsal region of its body, which promotes better pollen transfer. In a similar system, large bees carried over more pollen from the large flowers of Erythronium americanum and $E$. grandiflorum, promoting pollination of these species (Thomson 1986). As the number and position of the flowers and the nectar characteristics can act as an attraction for pollinators to visit more flowers (Sargent et al. 2007), a few open flowers per plant per day and the positioning of the reproductive structures in P. tenuiflora seem to be important for reproductive success.

Floral traits and availability of nectar by day and night led to the expectation that both diurnal and nocturnal visitors would be effective pollinators of $P$. tenuiflora (SanMartinGajardo \& Sazima 2005; Giménez-Benavides et al. 2007). However, our results showed that nocturnal visitors do not play a role in the reproduction of this species, as no fruit was set after flower exposition only at night. For the $57 \%$ of flowers that were left opened during the day and that did not set fruits, we believe in direct influence of flower manipulation during the experiment or in decrease of attractiveness to floral visitors after manipulation. As a consequence of these results, large diurnal bees were identified as the most effective pollinators of P. tenuiflora flowers, due to their visiting behaviour, frequency of visits and body size.

The floral features of $P$. tenuiflora, such as size, color, shape, nectar production, and time of exposure can provide resources for a wide range of floral visitors, whether they are pollinators or robbers. Frieseomelitta francoi can act as floral robbers (sensu Inouye 1983) by consuming pollen, but when they are consuming nectar they may contribute to attracting effective pollinators by indicating the availability of this resource (Tepedino \& Parker 1981). In a study in the USA, about $25 \%$ of all sampled floral visitors did not carry any conspecific pollen, and thus, they were not potential pollinators (Alarcón 2010). However, the role of floral visitors as robbers on P. tenuiflora needs to be better analyzed.
Paliavana tenuiflora has floral traits related to the melittophilous pollination syndrome, such as large, bellshaped, violet-purple flowers, as well as nectar sugar concentration and long anthesis (SanMartin-Gajardo \& Sazima 2004; 2005). Our work showed that the bees were effective pollinators of this plant, thus $P$. tenuiflora could be characterized by having a bee pollination system. Furthermore, the hummingbird P. pretrei may be a pollinator due to visiting behaviour, and this characterizes a mixed pollination system. However because of the low frequency of the visits, this species may be regarded as an occasional pollinator. Thus the importance of $P$. pretrei as pollinator of $P$. tenuiflora still needs to be better evaluated.

\section{Acknowledgements}

We thank Astrid Kleinert (USP), Nadia Roque (UFBA) and Marisol Amaya Marquez (Universidad Nacional de Colombia) for their contributions to this paper; Peter G. Kevan (UOGUELPH) for UV photos and for suggestions in the field to this study, and Leonardo Galetto (Universidad de Cordoba) for suggestions in the field to this study; Favízia Oliveira (UEFS) for identifying the bees; Antônio Brescovit (Butantan Institute - SP) for identifying the spiders; the Mucugê Municipal Park staff for help with logistics; Marianna Horn and Eric Glemser (UOGUELPH) for their contributions to this paper and their help in the field work, and to the anonymous reviewers who made important contributions to this work. We also thank Leonardo Stabile (UFBA) for his very important contributions to this study. Essential financial support was provided by FAPESP and CNPq.

\section{References}

Alarcón, R. 2010. Congruence between visitation and pollen-transport networks in a California plant pollinator community. Oikos 119: 35-44.

Araújo, A.O.; Souza, V.C. \& Chautems, A. 2005. Gesneriaceae da Cadeia do Espinhaço de Minas Gerais, Brasil. Revista Brasileira de Botânica 28: $109-135$.

Ashworth, L.; Aguilar, R.; Galetto, L. \& Aizen, M.A. 2004. Why do pollination generalist and specialist plant species show similar reproductive susceptibility to habitat fragmentation? Journal of Ecology 92: 717-719.

Baker, H.G.; Baker, I. \& Hodges, S.A. 1998. Sugar composition of nectars and fruits consumed by birds and bats in the tropics and subtropics. Biotropica 30: 559-586.

Barrett, S.C.H. 1998. The evolution of mating strategies in flowering plants. Trends in Plant Science 3: 335-341.

Buzato, S.; Sazima, M. \& Sazima, I. 2000. Hummingbird pollinated floras at three Atlantic forest sites. Biotropica 32: 824-841.

Chalcoff, V.R.; Aizen, M.A. \& Galetto, L. 2006. Nectar concentration and composition of 26 species from the temperate forest of South America. Annals of Botany 97: 413-421.

Corbet, S.A. 2003. Nectar sugar content: estimating standing crop and secretion rate in the field. Apidologie 34: 1-10.

Corbet, S.A. \& Willmer, P.G. 1981. The nectar of Justicia and Columnea: composition and concentration in a humid tropical climate. Oecologia 51: 412-418.

Dafni, A.; Kevan, P.G. \& Husband, B.C. 2005. Practical pollination biology. Ontario, Enviroquest Ltd.

Faegri, K. \& van der Pijl, L. 1979. The principles of pollination ecology. Oxford, Pergamon Press.

Fenster, C.B.; Armbruster, W.S.; Wilson, P.; Dudash, M.R. \& Thomson, J.D. 2004. Pollination syndromes and floral specialization. Annual Review of Ecology and Systematics 35: 375-403.

Funch, L.S.; Funch, R. \& Barroso, G.M. 2002. Phenology of gallery and montane forest in the Chapada Diamantina, Bahia, Brazil. Biotropica 34: $40-50$. 
Giménez-Benavides, L.; Dötterl, S.; Jürgens, A.; Escudero, A. \& Iriondo, J.M. 2007. Generalist diurnal pollination provides greater fitness in a plant with nocturnal pollination syndrome: assessing the effects of a Silene hadena interaction. Oikos 116: 1461-1472.

Hernández-Conrique, D. \& Ornelas, J.F. 2007. Nectar production of Calliandra longipedicellata (Fabaceae: Mimosoideae), an endemic Mexican shrub with multiple potential pollinators. Biotropica 39: 459-467.

Herrera, C.M. 1996. Floral traits and plant adaptation to insect pollinators: a devil's advocate approach. Pp. 65-87. In: Lloyd, D.G. \& Barrett, S.C.H. (eds.). Floral biology: studies on floral evolution in animalpollinated plants. New York, Chapman and Hall.

Inouye, D.W. 1983. The ecology of nectar robbing. Pp. 153-173. In: Elias, T.S. \& Bentley, B.L. (eds.). The biology of nectaries. New York, Columbia University Press.

Johnson, S.D. \& Steiner, K.E. 2000. Generalization versus specialization in plant pollination systems. Trends in Ecology and Evolution 15: 140-143.

Kearns, C.A. \& Inouye, D.W. 1993. Techniques for pollination biologists. Niwot, University Press of Colorado.

Kevan, P.G.; Grainger, N.D.; Mulligan, G.A. \& Robertson, A.R.A. 1973. Gray scale for measuring reflectance and color in the insect and human visual spectra. Ecology 54: 924-926.

Machado, I.C.S. \& Lopes, A.V. 2004. Floral traits and pollination systems in the Caatinga, a Brazilian tropical dry forest. Annals of Botany 94: 365-376.

Machado, I.C.S.; Sazima, I. \& Sazima, M. 1998. Bat pollination of the terrestrial herb Irlbachia alata (Gentianaceae) in Northeastern Brazil. Plant Systematics and Evolution 209: 231-237.

Perret, M.; Chautems, A. \& Spichiger, R. 2006. Dispersal vicariance analyses in the Tribe Sinningieae (Gesneriaceae): a clue to understanding biogeographical history of the Brazilian Atlantic Forest. Annals of the Missouri Botanical Garden 93: 340-358.

Perret, M.; Chautems, A.; Spichiger, R.; Barraclough, T.G. \& Savolainen, V. 2007. The geographical pattern of speciation and floral diversification in the Neotropics: the Tribe Sinningieae (Gesneriaceae) as a case study. Evolution 61: 1641-1660

Perret, M.; Chautems, A.; Spichiger, R.; Kite, G. \& Savolainen, V. 2003. Systematics and evolution of tribe Sinningieae (Gesneriaceae): evidence from phylogenetic analyses of six plastid DNA regions and nuclear ncpGS1. American Journal of Botany 90: 445-460.

Perret, M.; Chautems, A.; Spichiger, R.; Peixoto, M. \& Savolainen, V. 2001. Nectar sugar composition in relation to pollination syndromes in Sinningieae (Gesneriaceae). Annals of Botany 87: 267-273.

Proctor, M.; Yeo, P. \& Lack, A. 1996. The natural history of pollination. New York, Harper Collins Publishers.

Quinn, G. \& Keough, M. 2002. Experimental Design and Data Analysis for Biologists. New York, Cambridge University Press.
Rivera-Marchand, B. \& Ackerman, J.D. 2006 Bat pollination breakdown in the Caribbean columnar cactus Pilosocereus royenii. Biotropica 38: $635-642$

Sakagami, S.F.; Laroca, S. \& Moure, J.S. 1967. Wild bee biocenotics in São José dos Pinhais (PR), South Brazil. Preliminary report. Journal of the Faculty of Science, Hokkaido University, Series 6, Zoology 18: $57-127$.

SanMartin-Gajardo, I. \& Sazima, M. 2004. Non-euglossine bees also function as pollinators of Sinningia species (Gesneriaceae) in southeastern Brazil. Plant Biology 6: 506-512.

SanMartin-Gajardo, I. \& Sazima, M. 2005. Chiropterophily in Sinningieae (Gesneriaceae): Sinningia brasiliensis and Paliavana prasinata are bat pollinated, but $P$. sericiflora is not. Not yet? Annals of Botany 95: 1097-1103.

Sargent, R.D.; Goodwillie,C.; Kalisz, S.; \& Ree, R.H. 2007. Phylogenetic evidence for a flower size and number trade-off. American Journal of Botany 94: 2059-2062.

Smith, J.F.; Wolfram, J.C.; Brown, C.L.; Carroll, C.L. \& Denton, D.S. 1997. Tribal relationships in the Gesneriaceae: evidence from DNA sequences of the chloroplast gene ndhF. Annals of the Missouri Botanical Garden 84: 50-66.

Tepedino, V.J. \& Parker, F.D. 1981. The effect of flower occupancy on the foraging of flower visiting insects. Psyche 88: 321-329.

Thomson, J.D. 1986. Pollen transport and deposition by bumble bees in Erythronium: influences of floral nectar and bee grooming. Journal of Ecology 74: 329-341.

Underwood, A.J. 1997. Experiments in ecology. Their logical design and interpretation using analysis of variance. Cambridge, Cambridge University Press.

Varassin, I.G.; Trigo, J.R. \& Sazima, M. 2001. The role of nectar production, flower pigments and odour in the pollination of four species of Passiflora (Passifloraceae) in Southeastern Brazil. Botanical Journal of the Linnean Society 136: 139-152.

Waser, N.M.; Chittka, L.; Price, M.V.; Williams, N.M. \& Ollerton, J. 1996. Generalization in pollination systems, and why it matters? Ecology 77: $1043-1060$

Wesselingh, R.A.; Burgers, H.C.M. \& Den Nijs, H.C.M. 2000. Bumblebee pollination of the understorey shrub species in a tropical montane forest in Costa Rica. Journal of Tropical Ecology 16: 657-672.

Wiehler, H. 1983. A synopsis of neotropical Gesneriaceae. Selbyana 6: $1-219$.

Zimmer, E.A.; Roalson, E.H.; Skog, L.E.; Boggan, J.K. \& Idnurm, A. 2002. Philogenetic relationships in the Gesnerioideae (Gesneriaceae) based on nrDNAITS and cdDNA trnL-F and trnE_T spacer region sequences. American Journal of Botany 89: 296-311. 